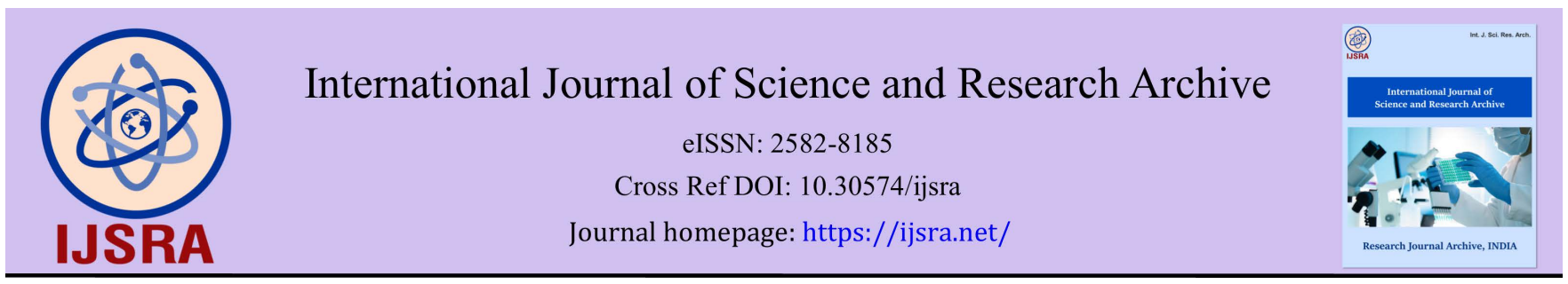

(RESEARCH ARTiClE)

\title{
Investigation of heavy metals in soil samples affected by burnt hospital waste using atomic absorption spectrophotometer
}

\author{
Akpan Okon Peter *, Etim Idopise Gabriel, Philip Peter Udeme and Emmanuel Asuquo Edet \\ Department of Science Technology, School of Applied Sciences Akwa Ibom State Polythechnic, Ikot Osurua, Nigeria.
}

International Journal of Science and Research Archive, 2022, 05(01), 108-113

Publication history: Received on 22 December 2021; revised on 07 February 2022; accepted on 09 February 2022

Article DOI: https://doi.org/10.30574/ijsra.2022.5.1.0202

\begin{abstract}
This research work was carried out to investigate heavy metals in soil samples affected by burnt hospital waste standards analytical procedure. The result reveals the presence of the following heavy metals concentration ranges from chromium (Cr) $0.90 \pm 0.12-1.20 \pm 0.00(\mathrm{mg} / \mathrm{kg}$ ), lead (Pb) 1.10 $\pm 0.0-2.20 \pm 0.11$ (mg/kg), Silicon (Si) 0.05 $\pm 0.03-$ $2.20 \pm 0.11$ (mg/kg), Cadmium (Cd) 0.55 $\pm 0.13-0.55 \pm 0.02$ (mg/kg), silver (Ag) 0.03 $\pm 0.01-0.05 \pm 0.03$ (mg/kg), Cobalt (Co) 0.06 $\pm 0.14-0.88 \pm$ inc $(\mathrm{Zn}) 10.00 \pm 0.01-11.12 \pm 0.11$ (mg/kg). However, higher concentrations were recorded for zinc, lead and chromium. Hence the need for proper method of disposing hospital waste is recommended and the health care waste managers should be educated on the implication of improper management of incinerator bottom ash and regulates monitor hospital waste generator sites.
\end{abstract}

Keywords: Heavy metals; soil; Hospital waste; Pollution

\section{Introduction}

Hospital waste are generated as a result of patient's diagnoses and treatment or immunization of human beings or animals. Hospital waste are universal set having subjects like infectious and hazardous wastes. Wrongly managed hospital waste can result in severe health hazards. It has been reported that Hospital waste is one of the toxic wastes.

Countries with little or no proper hospital waste management are prone to severe chronic respiratory syndrome (SARS). Several accidents have been reported where mishandling of hospital wastes is so infectious [1]. Hospital wastes are so infectious/hazardous that every means of improper disposal pose a threat to the environment. With the ever-increasing population of Nigerians, there is a corresponding increase in health care delivery / facility; the amount of hospital waste generated is also increasing substantially. The large amount of solid waste in generated in the hospital during diagnoses and treatment of diseases, the waste may contain human organs, bandages, syringe, test tube, tissues, cell culture and other plastic material. These wastes can cause health hazard, the incinerator is an effective and hygienic way of disposal of hospital waste. It is only in very few teaching hospitals in Nigeria that they exist functional incinerators. The dumping of infectious/toxic waste on the soil and sometimes burning them like the case in this study, can lead to contamination of crops and underground water which can cause very serious harm to unexpected consumers. Soil is a very specific component of the biosphere because it is not a geochemical sink for contaminants, but also acts as natural buffer controlling the transportation of chemical elements and substances to the atmosphere, hydroscope and biota. However, the most important role of soil is its productivity which is basic for human survival.

Hospital solid waste has been found to contain appreciable quantity of heavy metals such $\mathrm{Cd}, \mathrm{Zn}, \mathrm{Pb}$, and $\mathrm{Cu}$, all which may eventually end up in the soil and leached down the profile [2]. The problem of heavy metals is that they are not biodegradable and therefore accumulates in the environment.

\footnotetext{
${ }^{*}$ Corresponding author: Akpan Okon Peter

Department of Science Technology, School of Applied Sciences Akwa Ibom State Polythechnic, Ikot Osurua, Nigeria.

Copyright $(2022$ Author(s) retain the copyright of this article. This article is published under the terms of the Creative Commons Attribution Liscense 4.0.
} 
The pollution of the environment with heavy metals has become worldwide et al, problem during recent years [3]. It is the common feature in the zone to find huge refuse dumpsites within residential areas and along some major and minor roads $[4,5,6]$. The impact of solid waste on health and environment has been an issue of global concern over the years $[7,8,9]$. The physiochemical parameters of soil have reported to have a profound influence on the mobility and bioavailability of heavy metals [10]. Bioavailability and toxicity of heavy metals depends on metal speciation in sediments [11].

However, large amount of these heavy metals is released into the soil as a result of increased anthropogenic activities such as agricultural practices, industrial activities, energy consumption and waste disposal methods, thus leading to the concentration of the soil $[12,13,14]$.

\section{Material and methods}

\subsection{Material}

Materials used for the study are soil samples, maxing tape, black polythene bag shovel, meter rule, mortar, pestle, mash, weighing balance, heating mantle, measuring cylinder, digestion flask, filter paper, aqua regia medium and distilled water, Atomic Absorption Spectrophotometer (AAS).

\subsection{Study Area}

The study area is around General Hospital Complex located in Ikot Ekpene Local Government Area of Akwa Ibom State in South-South Nigeria, which lies between latitude $5^{0} 11$ and $5^{0} 183$ and Longitudes $7^{0} 43$ and $5^{0} 183$. The geology of the area forms a complex pattern of coarse and fined grained gneisses (Fig. 1).

\subsection{Collection of soil sample for analysis}

Soil samples were collected from burnt hospital waste dumpsite at different depth of $15 \mathrm{~cm}, 20 \mathrm{~cm}, 25 \mathrm{~cm}$ using a shovel to excavate the soil and the measurements were taken using a meter rule. The soil samples obtained were stored in different black polythene bags depending on their measurement and taken to the laboratory for analysis. Three samples were taken at the sampling location. The analysis was done using Atomic Adsorption Spectrophotometer (AAS).

Atomic Absorption Spectroscopy (AAS) is a Spectro analytical procedure element using the absorption of optical radiation (light) by free atoms in the gaseous state.

\subsection{Principle}

The Technique makes use of absorption Spectroscopy to access the concentration of an analyte in a sample. It requires Standards with known analyte content to establish the relation between the measured absorbance and the analyte concentration and relies therefore on the Beer-Lambert Law.

The electrons on the atoms in the atomizer can be promoted to higher orbitals (excited state) for a short period of time (nanoseconds) by absorbing a defined quantity of energy (radiation of a given wavelength). This amount of energy i.e., wavelength is specific to a particular electron transition in a particular element. In general, each wavelength corresponds to only one element, and the width of an absorption line is only of the order of a few picometer(pm), which gives the technique its element selectivity. The radiation flux without a sample and with a sample in the atomizer is measured using a detector, and the radio $\mathrm{b} / \mathrm{w}$ the two values (the absorbance) is converted to analyte concentration or mass using Beer-lambert law.

The Beer-Lambert law can be expressed thus: $A=\mathcal{E}$ LC

Where:

$\mathrm{A}=$ Absorbance

$\mathrm{E}=$ molar Absorptivity coefficient $\left(\mathrm{M}^{-1} \mathrm{CM}^{-1}\right)$

$\mathrm{L}=$ optical path Length $(\mathrm{M})$

$\mathrm{C}=$ Solution Concentration $(\mathrm{CM})$ 


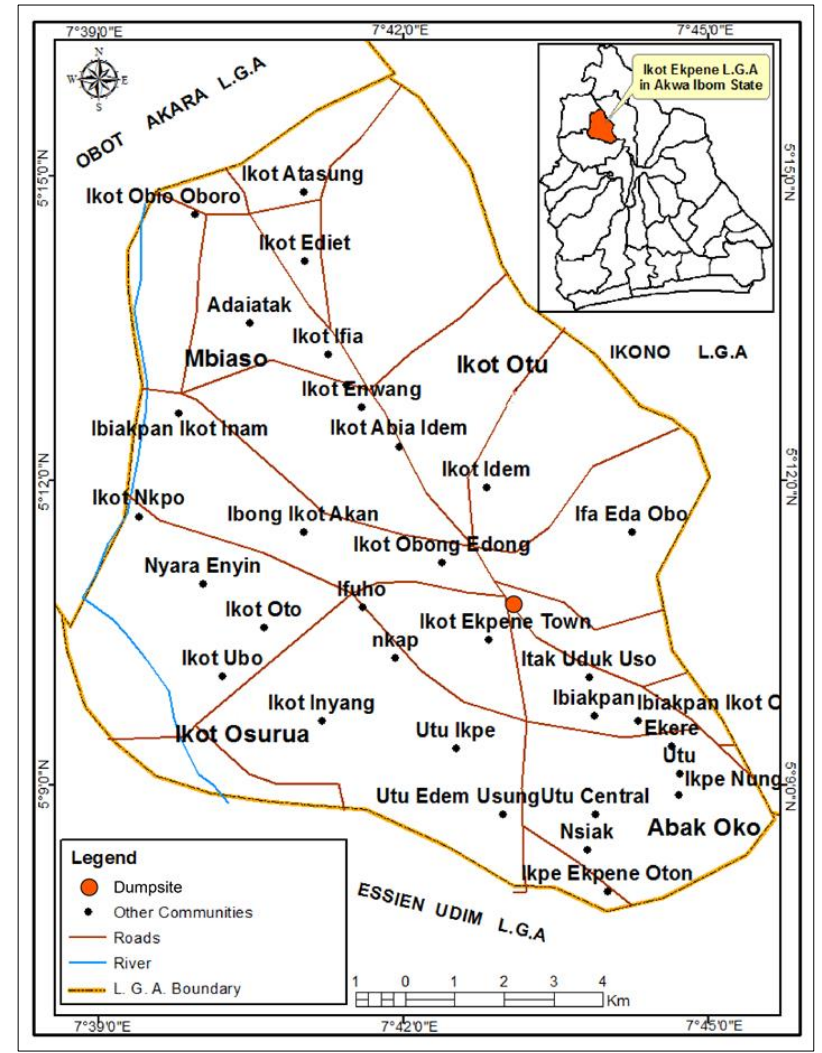

Figure 1 Map of Ikot Ekpene local government area

\subsection{Method of analysis}

\subsubsection{Samples Preparation}

For the analysis of concentration of selected trace metals ( $\mathrm{Cr}, \mathrm{Pb}, \mathrm{Si}, \mathrm{Co}, \mathrm{Ag}, \mathrm{Cd}, \mathrm{Zn})$, the soils samples were thoroughly mixed in clean plastic buckets before representative samples were collected. Furthermore, the samples were air dried for 72 hours and ground with mortar and pestle and finally sieved through $2 \mathrm{~mm}$ sieve to obtain fine powder (AOAC, 2000). The sample was stored in an airtight container and was taken to the ministry of science and technology, Obio Imo, Uyo for the analysis.

\subsubsection{Digestion of sample / determination of heavy metal}

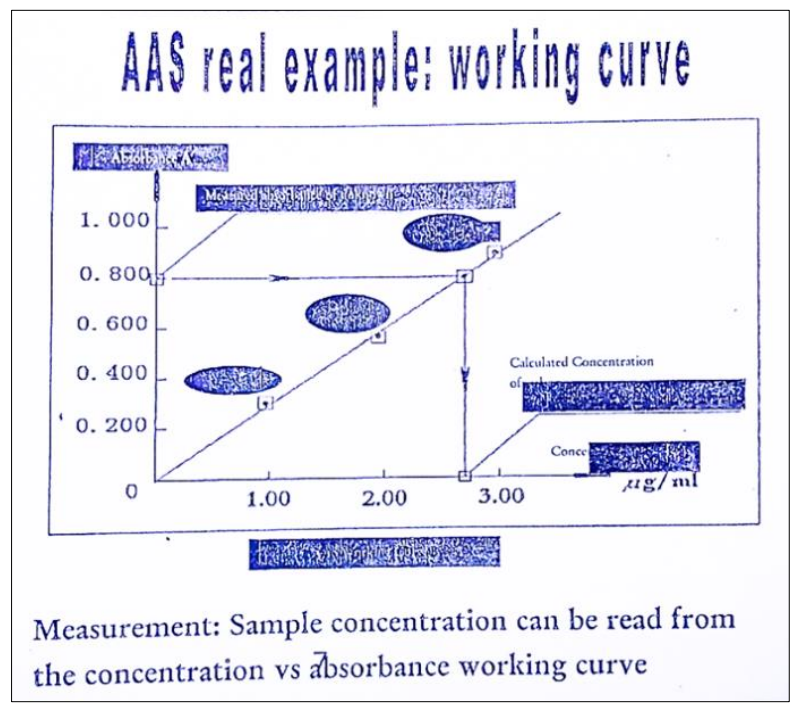

Figure 2 Calibration curve 
$1 \mathrm{~g}$ of the dried sample was digested using aqua regia medium at the ratio of $3: 1$ (i.e., $30 \mathrm{ml}$ of perchloric acid and $10 \mathrm{ml}$ of nitric acid) and then heated with heating mantle at $1300 \mathrm{C}$ until heavy brown fume ceased which led to the liberation of white fume to the digestion flask which shows complete digestion. Thereafter, the digest was allowed to cool and 30 $\mathrm{ml}$ of deionized water was added and filtered with Whiteman no. 1 filter paper up to mark with deionized water [18].

Furthermore, the concentrations of selected heavy metals were carried out using Atomic Adsorption Spectrophotometer (AAS).

\section{Results}

The result of heavy metals $(\mathrm{Cr}, \mathrm{Pb}, \mathrm{Si}, \mathrm{Co}, \mathrm{Ag}, \mathrm{Cd}, \mathrm{Zn})$ in selected soil samples from General Hospital, Ikot Ekpene are presented in Table 1 and Fig. 2 below.

Table 1 The results of concentration of heavy metal affected soil samples obtained from General Hospital, Ikot Ekpene

\begin{tabular}{|c|c|c|c|c|c|c|c|}
\hline SAMPLE ID DEPTH & $\operatorname{Cr}(\mathrm{Mg} / \mathrm{kg})$ & $\mathrm{Pb}(\mathrm{Mg} / \mathrm{kg})$ & $\mathrm{Si}(\mathrm{Mg} / \mathrm{kg})$ & Co $(\mathrm{Mg} / \mathrm{kg})$ & $\mathrm{Ag}(\mathrm{Mg} / \mathrm{kg})$ & $\mathrm{Cd}(\mathrm{Mg} / \mathrm{kg})$ & $\mathrm{Zn}(\mathrm{Mg} / \mathrm{kg})$ \\
\hline $15.0 \mathrm{~cm}$ & $1.00 \pm 0.15$ & $2.20 \pm 0.11$ & $0.12 \pm 0.01$ & $0.60 \pm 0.14$ & $0.03 \pm 0.01$ & $0.50 \pm 0.13$ & $10.50 \pm 0.01$ \\
\hline $20.0 \mathrm{~cm}$ & $0.90 \pm 0.12$ & $1.30 \pm 0.03$ & $0.20 \pm 0.14$ & $0.67 \pm 0.06$ & $0.03 \pm 0.01$ & $0.52 \pm 0.12$ & $10.51 \pm 0.32$ \\
\hline $25.0 \mathrm{~cm}$ & $1.20 \pm 0.01$ & $1.10 \pm 0.03$ & $0.05 \pm 0.02$ & $0.88 \pm 0.01$ & $0.05 \pm 0.13$ & $0.55 \pm 0.02$ & $11.12 \pm 0.11$ \\
\hline
\end{tabular}

Table 2 EPA Guideline for Soil

\begin{tabular}{|c|c|c|c|c|c|c|}
\hline \multirow{2}{*}{ Mg/Kg metal } & \multirow{2}{*}{ Not Polluted } & \multirow{2}{*}{ Moderate Polluted } & \multirow{2}{*}{ Polluted } & \multicolumn{3}{l|}{ Present Study } \\
\cline { 5 - 7 } & & & & $\mathbf{1 5 . 0}(\mathbf{c m})$ & $\mathbf{2 0 . 0}(\mathbf{c m})$ & $\mathbf{2 5 . 0}(\mathbf{c m})$ \\
\hline $\mathrm{Cr}$ & 0.05 & $0.05-60$ & $>60$ & $1.00 \pm 0.15$ & $0.90 \pm 0.12$ & $1.20 \pm 0.01$ \\
\hline $\mathrm{Pb}$ & 0.01 & $0.01-60$ & $>60$ & $2.20 \pm 0.11$ & $1.30 \pm 0.03$ & $1.10 \pm 0.03$ \\
\hline $\mathrm{Si}$ & 0.03 & $0.1-50$ & $>50$ & $0.12 \pm 0.01$ & $0.20 \pm 0.14$ & $0.05 \pm 0.02$ \\
\hline $\mathrm{Cd}$ & 0.1 & - & - & $0.50 \pm 0.13$ & $0.52 \pm 0.12$ & $0.55 \pm 0.02$ \\
\hline $\mathrm{Ag}$ & 0.03 & $0.03-25$ & $>25$ & $0.03 \pm 0.01$ & $0.03 \pm 0.01$ & $0.05 \pm 0.13$ \\
\hline $\mathrm{Co}$ & 0.06 & $0.06-50$ & $>50$ & $0.60 \pm 0.14$ & $0.67 \pm 0.06$ & $0.88 \pm 0.01$ \\
\hline $\mathrm{Zn}$ & 3.0 & $3.0-100$ & $>100$ & $10.50 \pm 0.01$ & $10.51 \pm 0.32$ & $11.12 \pm 0.11$ \\
\hline
\end{tabular}

\section{Discussion}

The investigation of heavy metals in soil samples affected by burnt hospital waste was carried out and the result of Chromium (Cr) ranges from $0.90 \pm 0.12(\mathrm{mg} / \mathrm{kg}$ ) to $1.20 \pm 0.01$. this result shows that the level of $\mathrm{Cr}$ in the samples were not within EPA permissible level of Chromium (Cr) $(0.05 \mathrm{mg} / \mathrm{kg})$ in the soil. (Table 2), thus the location can be said to be polluted.

The level of Lead $(\mathrm{Pb})$ in the samples ranges from $1.10 \pm 0.03(\mathrm{mg} / \mathrm{kg})$ to $0.12 \pm 0.01(\mathrm{mg} / \mathrm{kg})$. Lead $(\mathrm{Pb})$ contents in the samples were higher than EPA guideline of $\mathrm{Pb}$ which is $0.01(\mathrm{mg} / \mathrm{kg})$, Hence these locations are moderately polluted with Lead $(\mathrm{Pb})$. Eating and drinking Lead $(\mathrm{Pb})$ contaminated food and water results in anemia, damaged kidney, liver and brain cells, other effects include abnormal pains irritability, nausea, tiredness, etc [14].

The level of Silicon (Si) ranges between $0.05 \pm 0.02(\mathrm{mg} / \mathrm{kg})$ to $0.20 \pm 0.14(\mathrm{mg} / \mathrm{kg})$, this result shows that only soil at location $25.0 \mathrm{~cm}$ is not polluted because it corresponds with $0.05(\mathrm{mg} / \mathrm{kg})$ guideline, but the level of the presence of Silicon (Si) at location $15.0 \mathrm{~cm}$ and $20.0 \mathrm{~cm}$ respectively are higher than the EPA guideline for sediment, thus they are polluted. 
The level of Cobalt (Co) ranges between $0.60 \pm 0.14 \mathrm{~m}(\mathrm{mg} / \mathrm{kg}$ ) to $0.88 \pm 0.01(\mathrm{mg} / \mathrm{kg})$, these results shows that all the results were higher than normal concentration range of EPA standard. Which is 0.06 (mg/kg), thus these locations are polluted.

The level of Silver (Ag) ranges between $0.03 \pm 0.01(\mathrm{mg} / \mathrm{kg})$ to $0.05 \pm 0.13(\mathrm{mg} / \mathrm{kg})$. This appears to be within the normal concentration range of EPA standard which is $0.03(\mathrm{mg} / \mathrm{kg})$.

The value of Cadmium (Cd) obtained ranges between $0.50 \pm 0.13(\mathrm{mg} / \mathrm{kg}$ ) to $0.55 \pm 0.02(\mathrm{mg} / \mathrm{kg})$, these results were higher than EPA standard, which is $0.1(\mathrm{mg} / \mathrm{kg})$ as such this calls for proper treatment of the soil.

The level of Zinc (Zn) obtained ranges between $10.50 \pm 0.01(\mathrm{mg} / \mathrm{kg})$ to $11.12 \pm 0.11(\mathrm{mg} / \mathrm{kg})$ compared to EPA standard which is $3.0(\mathrm{mg} / \mathrm{kg})$ to $100(\mathrm{mg} / \mathrm{kg})$, thus these locations are moderately polluted with zinc. Excess zinc leads to nausea, gastric irritation, lethargy, anemia and can affect cardiac function (Willacy, 2019).

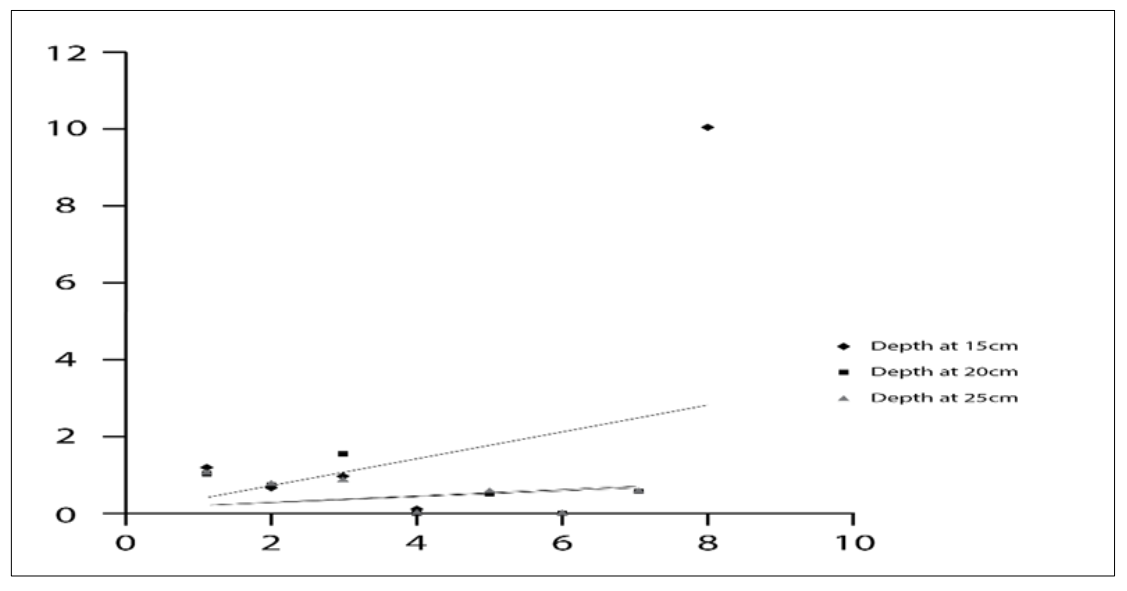

Figure 3 A Graph of Samples against Depth

\section{Conclusion}

In this study, soil in the three depths in the same location within hospital environment were analysed using Atomic Adsorption Spectrophotometer (AAS) for seven heavy metals ( $\mathrm{Cr}$, Pb, Si, Co, Ag, Cd, Zn). Sampling points were chosen in such a manner as to cover the entire vicinity under study. However, it can therefore be concluded that Hospital waste are so infectious (hazardous that mean improper disposal pose a threat to the environment). Plants growing on heavy metals, polluted soil shows a reduction in growth due to change in their physiological and biochemical activities, this is essential when the heavy metals involved does not play any beneficial role towards the growth and development of plants.

\section{Recommendation}

Based on this result obtained, the following recommendations were made.

- Human activities which release heavy metals which are injuries to soil dwelling organisms and man should be regulated and closely monitored by government agencies and institutions.

- $\quad$ More strategies must be put in place to prompt current industrial operation to take precaution and new techniques to protect the environment from hazardous pollutant. The reason being that the human body is of a complex structure. Therefore, the accumulation of elements can cause many toxic effects which can influence different mechanism on the body.

\section{Compliance with ethical standards}

\section{Acknowledgments}

We acknowledge the contributions of technologists in Ministry of Science and Technology, Akwa Ibom State. Nigeria. And Mr Aniekan E. Akpakpan, Department of Chemistry, Akwa Ibom State University, Nigeria. 


\section{Disclosure of conflict of interest}

The authors declare that there is no conflict of interest.

\section{References}

[1] Shang Hy, Jia HQ. Present situation and disposal of medical waste in China. J. Environ. Pollute control. 2002; 24: $1101-3868$.

[2] Khans, Wanns. Heavy Metal is only Toxic when its Concentration in Plants and Animals Exceeds a Certain Threshold. 2011.

[3] Benjamin M, Mwashot. Levels of Caesium and Lead in Water, Sediment and Selected Fish Species in Mombase Kenya Western Indian Oceanic J. Mar. Sci. Sci. 2003; 2: 25-34.

[4] Elaigwu SE, VOA Ajibola, FM Folaranm. Studies on the Impact of Municipal Waste Dumps on Surrounding Soil and air Quality of Two Cities in Northern Nigeria. J. Applied Sci. 2007; 7: 421 - 425.

[5] Odukoya 00, O Bamgbose, TA Arowolo. Heavy Metals in Topsoil of Abeokuta Dumpsites. Global. J. Pure applied Sci. 2002; 7: $467-472$.

[6] Udosen EDE, I Udoessien, UJ Ibok. Evaluation of Some Metals in the Industrial Waste from Paint Industry and their Environment Pollution Implications. Nig. J. Technol. Res. 1990; 2: 71 - 77.

[7] Goorah SS, ML Esmyot, R Boojhawon. The Health Impact of Non-Hazardous Soil Waste Disposal in a Community. The Case of the Mare Chicose Land fill in Mauritus. J. Environ Health. 2009; 72: 48 - 54.

[8] Kouznetsova MX, Huang JMa, LL Lessner, DO Carpenter. Increased Rate of Hospitalization for Diabetes and Residential Proximity of Harzardus Waste Sites. Environ Health Perspect. 2007; 115: 75-79.

[9] Barlaz MP, Kaplan S Ranjithan, R Rynk. Evaluating Environmental Impacts of Solid Waste Management Alternatives. Biocycle. 2003; 1: 52-56.

[10] Tukura BW, JA Kagbu, CE Gimba. Effect of PH and Total Organic Carbon (TOC) on the Distribution of Trace Metals in Kubanni Dam Sediments, Zaria. Sci. World. J. 2007; 2: 1-6.

[11] Ebong GAMM, Akpan, VN Mkpenie. Heavy Metals Contents of Municipal and Rural Dumpsite Soil and Rate of Accumulation by Carica Papaya and Talinum Triangulare in Uyo, Nigeria. J, Chem. 2008; 5: 281 - 290.

[12] Ewa-Szarak GA, Amrowiez, R Gwazda. Trace Elements Concentration in Fish and Bottom Sediments or Autotrophic Dam. Reservour. Int. J Hydrol. 2006; 35: 331352.

[13] Eja MEOR Ogri, GE Arikpo. Bioconcentration of Heavy Metals in Surface Sediments from the Great Kwa River estuary, Calabar, Southeastern Nigeria, Environ. Soc. 2003; 1: 247 - 256.

[14] Ndiokwere CL, CA Ezihe. The occurrence of heavy metals in the vicinity of industrial complexes in Nigeria, Environ. Int. 1990; 16: $291-295$.

[15] Akpan IO, Iiwah EJ, Osadebe FAN. Elementary Analysis of Nigeria Crude Oil using Atomic Absorption Spectroscopy, Newtron Activation Analysis and Total Reflection X-ray florescence technique, Nigeria Journal of physical Sciences. 2006; 7.

[16] Willacy H. Zinc Deficiency, Excess and Supplementation. 2019.

[17] AOAC. Official methods of Analysis, 15 E.D. Association of Official Analytical Chemists, Washington, Dc. 2000.

[18] Haswell, S. J. Atomic Absorption Spectrometry: Theory, Design and Application. Elsevier Amsterdam. 2011. 